\title{
Doctors' view about status of Teaching \& Learning of Psychiatry at Undergraduate Medical Education in Bangladesh
}

\begin{abstract}
Hasan MK', Aktar MT2 ${ }^{3}$, Begum SA3, Kabir FR ${ }^{4}$, Islam $R^{5}$
\section{Abstract}

This descriptive type of cross-sectional study was carried out at different Upazilla levels hospitals of Dhaka, Chattogram, Khulna, Sylhet, Rajshahi, Barisal \& Rangpur divisions. It was conducted to find out the views of the doctors serving at primary health care level about the status of teaching \& learning of Psychiatry at undergraduate medical education level in Bangladesh. The contents, teaching-learning hours, teaching-learning methods \& assessment needed for Psychiatry of undergraduate medical curriculum 2002 \& 2012 of Bangladesh were also reviewed \& compared by the researcher. The study period was July 2019 to June 2020. A self-administered semi-structured questionnaire with five-point Likert scale was used. Convenience sampling technique was adopted \& total 307 doctors participated in this study with their valuable opinions.
\end{abstract}

After reviewing and comparing of undergraduate curriculum $2002 \& 2012$, it was found that content coverage $\& 20$ hours lecture in psychiatry was same in both curricula. But block posting was reduced from 5 days to 3 days \& ward placements was reduced from 4 weeks to 3 weeks in the curriculum of 2012 from curriculum of 2002. In curriculum 2002, there were 17.5 marks in written and 01 OSCE station in practical for Psychiatry and one examiner from either Psychiatry or Dermatology in paper II of Medicine in final professional MBBS examination. But there is no such provision for psychiatry in curriculum 2012.

Among 307 doctors, 287 (86.9\%) agreed that behavioral science should be taught by Psychiatrist instead of Community Medicine Specialist. Only 36 (11.8\%) respondents agreed that their learning \& training in psychiatry were sufficient during MBBS. Although, 227 (73.9\%) doctors agreed that in their practice, a major portion of the patients were suffering from psychiatric problem, only $84(27.4 \%)$ of them were confident enough to manage common Psychiatric cases. Among respondents, $238(77.6 \%)$ agreed that placement of MBBS students in psychiatry should be from $3^{\text {rd }}$ year and $260(84.7 \%)$ agreed that Psychiatry should be given more weightage in MBBS curriculum. Around 180 (58.4\%) doctors agreed that Psychiatry should be a separate subject as per standard set by WFME. Regarding examinership, 69\% (212) respondents agreed that there should be one examiner from psychiatry in MBBS final Professional examination and 86.9\% (267) of the respondents agreed that the Psychiatric part of MBBS curriculum should be updated immediately. The study recommended to update the psychiatric portion of MBBS Curriculum considering psychiatry as a separate subject as per the directive of WFME \& like many countries of the world.

Key words: Psychiatry, Teaching-Learning, Undergraduate medical education, Doctors.

1. Brig Gen (Dr) M Kumrul Hasan, Adviser Specialist \& Head of the Department, Psychiatry, CMH Dhaka Cantonment

2. Dr Muqbula Tasrin Aktar, Associate Professor, Pharmacology, NIO\&H, Dhaka

3. Dr Ara SA, Professor \& Head of the Department, Microbiology with Pathology, Dhaka Dental College, Dhaka

4. Dr Fuad Reajwan Kabir, Assistant Professor, Dental Anatomy, Saphena Women's Dental College, Dhaka

5. Brig Gen (Dr) Md. Rafiqul Islam, DMS (Army), Army Headquarters, Dhaka

Address of correspondence: M. Kumrul Hasan, Professor, Psychiatry, CMH, Dhaka,

email: kumru12002@gmail.com

Bangladesh Journal of Medical Education 2021; 12(2); Hasan et al., publisher and licensee Association for Medical Education Bangladesh. This is an Open Access article which permits unrestricted noncommercial use, provided the original work is properly cited. 


\section{Introduction}

Most of the medical students will not become psychiatrists. For these students, the psychiatry lectures and clinical posting will be the only experiences on psychiatric practice before they begin to work as doctors. ${ }^{1}$ Knowledge of psychiatry is important for all doctors, because prevalence of mental illness ranges from 65 to 314 per 1000 population. $^{2}$

Many of the psychiatric morbidity is not detected by the treating team in medical and surgical wards. The training that the undergraduate gets will change this situation. Currently, undergraduate students have multiple lacunae in their knowledge of psychiatry. ${ }^{3}$

Psychiatry has a very thin slice of the medical curriculum "cake." The situation is reflected similarly in the other South Asian countries. Sri Lanka is an exception, and most colleges have eight or more weeks of training in psychiatry; and also, in most medical colleges, Psychiatry is one of the subjects in the final exams. It is an unfortunate paradox that the countries in which there are least resources for Psychiatry teaching are generally those in which the need is the greatest. ${ }^{4}$

The progress of a country is linked closely with the mental health of its individuals. Mental health and poverty form a vicious circle and there cannot be development without good mental health. Promoting mental health is thus very critical and this cannot happen without quality psychiatric training in the country. There are very few studies addressing the quality of psychiatric teaching-learning in the country. ${ }^{5}$

\section{Methods and Material}

This is a descriptive type of cross-sectional study. The study was conducted among 307 doctors from different Upazilla level of Dhaka, Khulna, Chattogram, Rajshahi, Sylhet, Rangpur, Mymensingh division. The study has been conducted during the period of July 2019 to June 2020 using a pre-tested self-administered semistructured questionnaire. The questionnaire was distributed among the doctors from different Upazilla and was collected immediately after completion. Doctors' participation was voluntary. Confidentiality and anonymity were strictly maintained. All ethical issues were considered and necessary permission was taken from ethical committee of the Centre for Medical Education (CME). Doctors were selected conveniently. After collection, data were checked and then entered into the software of the computer for analysis. SPSS program (IBM SPSS statistics 19) was used for data analysis. Likert scale was used to measure responses.

\section{Results}

Out of 307 respondents, male graduates were more (178) than female (129) in medical colleges. But females were more in non-government medical colleges $(60.47 \%)$ than government medical colleges $(34.84 \%)$.

Bangladesh Journal of Medical Education 2021; 12(2); Hasan et al., publisher and licensee Association for Medical Education Bangladesh. This is an Open Access article which permits unrestricted non-commercial use, provided the original work is properly cited. 


\section{Table 1: Distribution of respondents as per their views about contents \& teaching learning hours related to Psychiatry in MBBS curriculum}

\begin{tabular}{|c|c|c|c|c|c|c|}
\hline \multirow{2}{*}{$\begin{array}{l}\text { Statement related to curriculum } \\
\text { contents \& teaching learning hours } \\
\text { of Psychiatry }\end{array}$} & \multicolumn{5}{|c|}{ Level of Agreement } & \multirow[b]{2}{*}{ Total } \\
\hline & $\begin{array}{c}\text { SA } \\
\mathbf{f}(\%)\end{array}$ & $\begin{array}{c}\mathrm{A} \\
\mathbf{f}(\%)\end{array}$ & $\begin{array}{l}\text { NAND } \\
\text { f }(\%)\end{array}$ & $\begin{array}{c}\mathrm{D} \\
\mathbf{f}(\%)\end{array}$ & $\begin{array}{c}\text { SD } \\
\mathbf{f}(\%)\end{array}$ & \\
\hline $\begin{array}{l}\text { Content coverage in Psychiatry was } \\
\text { adequate }\end{array}$ & $\begin{array}{c}24 \\
(7.8)\end{array}$ & $\begin{array}{c}107 \\
(34.9)\end{array}$ & $\begin{array}{c}35 \\
(11.4)\end{array}$ & $\begin{array}{c}103 \\
(33.6)\end{array}$ & $\begin{array}{c}38 \\
(12.4)\end{array}$ & 307 \\
\hline $\begin{array}{l}\text { In my curriculum, the number of } \\
\text { Lecture in psychiatry was sufficient }\end{array}$ & $\begin{array}{c}12 \\
(3.9)\end{array}$ & $\begin{array}{c}85 \\
(27.7)\end{array}$ & $\begin{array}{c}37 \\
(12.1)\end{array}$ & $\begin{array}{l}132 \\
(43)\end{array}$ & $\begin{array}{c}41 \\
(13.4)\end{array}$ & 307 \\
\hline $\begin{array}{l}\text { There should be tutorial classes for } \\
\text { psychiatry }\end{array}$ & $\begin{array}{c}113 \\
(36.8)\end{array}$ & $\begin{array}{c}146 \\
(47.6)\end{array}$ & $\begin{array}{c}21 \\
(6.8)\end{array}$ & $\begin{array}{c}21 \\
(6.8)\end{array}$ & $\begin{array}{c}6 \\
(2.0)\end{array}$ & 307 \\
\hline $\begin{array}{l}\text { As per the curriculum } 03 \text { weeks } \\
\text { placement in psychiatry in } 5^{\text {th }} \text { year } \\
\text { was sufficient }\end{array}$ & $\begin{array}{c}22 \\
(7.2)\end{array}$ & $\begin{array}{c}98 \\
(31.9)\end{array}$ & $\begin{array}{c}74 \\
(24.1)\end{array}$ & $\begin{array}{c}85 \\
(27.7)\end{array}$ & $\begin{array}{c}27 \\
(8.8)\end{array}$ & 306 \\
\hline $\begin{array}{l}\text { Practically, I was placed in } \\
\text { psychiatry only for few days }\end{array}$ & $\begin{array}{c}66 \\
(21.5)\end{array}$ & $\begin{array}{c}177 \\
(57.7)\end{array}$ & $\begin{array}{c}11 \\
(3.6)\end{array}$ & $\begin{array}{c}36 \\
(11.7)\end{array}$ & $\begin{array}{c}17 \\
(5.5)\end{array}$ & 307 \\
\hline $\begin{array}{l}\text { There is no need of readjustment of } \\
\text { psychiatric portion in the curriculum }\end{array}$ & $\begin{array}{c}12 \\
(3.9)\end{array}$ & $\begin{array}{c}28 \\
(9.1)\end{array}$ & $\begin{array}{c}39 \\
(12.7)\end{array}$ & $\begin{array}{c}117 \\
(38.1)\end{array}$ & $\begin{array}{c}111 \\
(36.2)\end{array}$ & 307 \\
\hline $\begin{array}{l}\text { Behavioral science should be taught } \\
\text { by Psychiatrist instead of Community } \\
\text { Medicine Specialist }\end{array}$ & $\begin{array}{c}141 \\
(45.9)\end{array}$ & $\begin{array}{l}126 \\
(41)\end{array}$ & $\begin{array}{c}22 \\
(7.2)\end{array}$ & $\begin{array}{c}11 \\
(3.6)\end{array}$ & $\begin{array}{c}7 \\
(2.3)\end{array}$ & 307 \\
\hline
\end{tabular}

Table 2: Distribution of respondents as per their views about ways \& means for further improvement of teaching, learning and assessment of Psychiatry

\begin{tabular}{|c|c|c|c|c|c|c|}
\hline \multirow{2}{*}{$\begin{array}{l}\text { Issues related to ways \& means for } \\
\text { further improvement of teaching, } \\
\text { learning and assessment of Psychiatry }\end{array}$} & \multicolumn{5}{|c|}{ Level of agreement } & \multirow[b]{2}{*}{ Total } \\
\hline & $\begin{array}{l}\text { SA } \\
(5)\end{array}$ & $\begin{array}{c}\text { A } \\
(4)\end{array}$ & $\begin{array}{l}\text { NAND } \\
\text { (3) }\end{array}$ & $\begin{array}{c}\text { D } \\
(2)\end{array}$ & $\begin{array}{l}\text { SD } \\
(1)\end{array}$ & \\
\hline $\begin{array}{l}\text { There should be placement in } \\
\text { psychiatry from } 3^{\text {rd }} \text { year }\end{array}$ & $\begin{array}{c}84 \\
(27.4)\end{array}$ & $\begin{array}{c}154 \\
(\mathbf{5 0 . 2})\end{array}$ & $\begin{array}{c}39 \\
(12.7)\end{array}$ & $\begin{array}{c}23 \\
(7.5)\end{array}$ & $\begin{array}{c}6 \\
(2.0)\end{array}$ & 306 \\
\hline $\begin{array}{l}\text { Psychiatry should be given more } \\
\text { weightage in MBBS course }\end{array}$ & $\begin{array}{c}90 \\
(29.3)\end{array}$ & $\begin{array}{c}170 \\
(\mathbf{5 5 . 4})\end{array}$ & $\begin{array}{c}30 \\
(9.8)\end{array}$ & $\begin{array}{c}17 \\
(5.5)\end{array}$ & - & 307 \\
\hline $\begin{array}{l}\text { I think Psychiatry should be a separate } \\
\text { major subject as per standard set by } \\
\text { World Federation of Medical } \\
\text { Education (WFME) }\end{array}$ & $\begin{array}{c}53 \\
(\mathbf{1 7 . 3})\end{array}$ & $\begin{array}{c}127 \\
(41.4)\end{array}$ & $\begin{array}{c}67 \\
(21.8)\end{array}$ & $\begin{array}{c}46 \\
(15.0)\end{array}$ & $\begin{array}{c}14 \\
(4.6)\end{array}$ & 307 \\
\hline $\begin{array}{l}\text { Teaching and learning of this subject } \\
\text { need to be more clinically oriented }\end{array}$ & $\begin{array}{c}134 \\
(43.6)\end{array}$ & $\begin{array}{c}156 \\
(\mathbf{5 0 . 8})\end{array}$ & $\begin{array}{c}8 \\
(2.6)\end{array}$ & $\begin{array}{c}7 \\
(2.3)\end{array}$ & $\begin{array}{c}2 \\
(0.7)\end{array}$ & 307 \\
\hline $\begin{array}{l}\text { There should be one examiner from } \\
\text { psychiatry in MBBS final Professional } \\
\text { examination }\end{array}$ & $\begin{array}{c}68 \\
(22.1)\end{array}$ & $\begin{array}{c}144 \\
(46.9)\end{array}$ & $\begin{array}{c}56 \\
(18.2)\end{array}$ & $\begin{array}{c}30 \\
(9.8)\end{array}$ & $\begin{array}{c}9 \\
(2.9)\end{array}$ & 307 \\
\hline $\begin{array}{l}\text { The Psychiatric part of MBBS } \\
\text { curriculum should be updated }\end{array}$ & $\begin{array}{c}122 \\
(39.7)\end{array}$ & $\begin{array}{c}145 \\
(47.2)\end{array}$ & $\begin{array}{c}29 \\
(9.4)\end{array}$ & $\begin{array}{c}9 \\
(2.9)\end{array}$ & $\begin{array}{c}2 \\
(0.7)\end{array}$ & 307 \\
\hline
\end{tabular}

Bangladesh Journal of Medical Education 2021; 12(2); Hasan et al., publisher and licensee Association for Medical Education Bangladesh. This is an Open Access article which permits unrestricted non-commercial use, provided the original work is properly cited. 


\section{Discussion}

During assessing the opinion of our doctors regarding psychiatric component, $259(88.4 \%)$ doctors agreed that there should be tutorial classes for psychiatry. Majority $228(74.3 \%)$ of the respondents disagreed on the question that there is no need of readjustment of psychiatric portion in the curriculum. Most of the doctors i.e., $267(87 \%)$ agreed that behavioral science should be taught by Psychiatrist instead of Community Medicine Specialist, among them $141(45.9 \%)$ were strongly agreed.

If we look towards India, we found that the working committee of national mental health program of India (NMHP) stressed that the amount and content of undergraduate psychiatric training be altered to address the mental health needs of their country. ${ }^{6}$

The behavioral science is taught by the department of psychiatry in different countries like Pakistan (Mohan Isaac et al. 2018), Sri Lanka ${ }^{7}$ Australia, Mexico, Saudi Arabia, Thailand, UK, USA ${ }^{8}$ etc.

The study asked the opinion of the doctors on few specific issues for further development of psychiatry at undergraduate level. Here the respondent didn't have any ambiguity. Most of the respondents, $238(77.6 \%)$ were agreed that placement of MBBS students in psychiatry should be from $3^{\text {rd }}$ year and $260(84.7 \%)$ agreed that psychiatry should be given more weightage in our MBBS. 180 $(58.4 \%)$ doctors agreed and only 60 $(19.6 \%)$ disagreed that Psychiatry should be a separate major subject as per standard set by WFME (World Federation of Medical Education) and $94.4 \%$ doctors agreed that teaching and learning of this subject need to be more clinically oriented. Regarding examinership, 69\% (212) respondent agreed that there should be one examiner from psychiatry in MBBS final Professional examination and $86.9 \%$ (267) of the respondent agreed that the Psychiatric part of MBBS curriculum should be updated immediately.

If we look at the world, we can find that clinical attachments at medical schools in UK in psychiatry is 6 to 12 weeks in few institutes. ${ }^{9}$ At other places, 80 hoursteaching in behavioral science course during basic medical science education, 36 weeks- devoted to learning interview skills and psychiatry history-taking once a day, 3 months full time Psychiatry clerkship, this is generally followed by a university examination. In Australia \& New Zealand total amount of teaching provided ranged from 285 to 534 hours, mean 416 hours clinical attachments occupied the bulk of teaching time. In India, AIIMS model. ${ }^{10}$ Total 9 weeks of clinical postings and compulsory logbook, integration with community medicine, 6 weeks' clinical postings at Comprehensive Rural Health Services Project (CRHSP), Ballabgarh in 7th semester. ${ }^{11}$

\section{Conclusion:}

Both the quality and quantity of undergraduate medical teaching \& learning in psychiatry are inadequate to meet forecast mental health needs. To prepare man future doctors to meet the rising disease burden of common mental disorders our undergraduate curriculum must be revised accordingly. There is a need to broaden the clinical experience of students to better equip them for future medical practice. There appears to be serious mis-match between the settings in which most students are taught and the settings in which most will work later as non-psychiatric practitioners.

Bangladesh Journal of Medical Education 2021; 12(2); Hasan et al., publisher and licensee Association for Medical Education Bangladesh. This is an Open Access article which permits unrestricted non-commercial use, provided the original work is properly cited. 
The data presented here will stimulate discussion and consideration of teaching of undergraduate teaching-learning on psychiatry in Bangladesh in the light of the needs of future doctors and current best educational practice. It may be a stepping stone in the advancement of undergraduate psychiatric education in Bangladesh.

\section{References:}

1. Manohari SM, Pradeep R. Johnson, and Ravindra Baburao Galgali, 'How to Teach Psychiatry to Medical Undergraduates in India: A Model' Indian J Psychol Med. 2013 Jan-Mar; 35(1): 23-28.

2. Chowdhury AK, Alam MN, Ali SMK, 1981. Dasherkandi project studies. Demography, morbidity and mortality in a rural community of Bangladesh. Bangladesh Med Res Counc Bull;7(1):22-39.

3. Chawla JM, Balhara YP, Sagar R, Shivaprakash, 'Undergraduate medical students' attitude toward psychiatry: A cross-sectional study'. Indian J Psychiatry; 2012. 54:37-40.

4. Trivedi JK and Mohan Dhyani, 'Undergraduate psychiatric education in South Asian countries' Indian J Psychiatry, 2007, Vol.49 No.3, pp. 163-165.

5. Srinivasa SRR Yerramilli, Y V Siva Sanakara Murty, Psychiatric education in India: need for reforms. AP J Psychol Med 2012; 13(1):1722.
6. Kallivayalil, R.A.. The importance of psychiatry in undergraduate medical education in India. Indian J. Psychiatry, 2012, 54 (3), 208-216.

7. $\mathrm{S} \mathrm{T}$ Kathriarachchi, $\mathrm{S} \mathrm{R}$ Dharmasena, Undergraduate training in psychiatry in a developing country -experience in establishing a new curriculum. Journal of the Ceylon College of Physicians, 2002, 35, 4-11

8. Anna Chur-Hansen, John E. Carr, Christine Bundy, Juan Jose SanchezSosa, Sombat Tapanya, Saeed H. Wahass, An International Perspective on Behavioral Science Education in Medical Schools. J Clin Psychol Med Settings; 2008. 15(1):45-53.

9. Dale JT, Bhavsar V, Bhugra D,. 'Undergraduate medical education of Psychiatry in the West'. Indian J Psychiatry; 2019, 49:166-8.

10. Sood, M., Sharan, P., A pragmatic approach to integrating mental health in undergraduate training: the AIIMS experience and work in progress. Nat. Med. J. India, 2011. 24 (2), 108-110.

11. Pawan Kumar, Purushottam Jangid and Sujata Sethi, Undergraduate psychiatry in India: A SWOT analysis Asian Journal of Psychiatry 2018, 33 (2018) 46-51

Bangladesh Journal of Medical Education 2021; 12(2); Hasan et al., publisher and licensee Association for Medical Education Bangladesh. This is an Open Access article which permits unrestricted non-commercial use, provided the original work is properly cited. 